\title{
Review Article \\ Development of Synthetic and Natural Materials for Tissue Engineering Applications Using Adipose Stem Cells
}

\author{
Yunfan He and Feng Lu \\ Department of Plastic and Cosmetic Surgery, Nanfang Hospital, Southern Medical University, Guangzhou, Guangdong 510515, China \\ Correspondence should be addressed to Feng Lu; doctorlufeng@hotmail.com
}

Received 16 October 2015; Revised 9 January 2016; Accepted 12 January 2016

Academic Editor: Norbert Pallua

Copyright (C) 2016 Y. He and F. Lu. This is an open access article distributed under the Creative Commons Attribution License, which permits unrestricted use, distribution, and reproduction in any medium, provided the original work is properly cited.

\begin{abstract}
Adipose stem cells have prominent implications in tissue regeneration due to their abundance and relative ease of harvest from adipose tissue and their abilities to differentiate into mature cells of various tissue lineages and secrete various growth cytokines. Development of tissue engineering techniques in combination with various carrier scaffolds and adipose stem cells offers great potential in overcoming the existing limitations constraining classical approaches used in plastic and reconstructive surgery. However, as most tissue engineering techniques are new and highly experimental, there are still many practical challenges that must be overcome before laboratory research can lead to large-scale clinical applications. Tissue engineering is currently a growing field of medical research; in this review, we will discuss the progress in research on biomaterials and scaffolds for tissue engineering applications using adipose stem cells.
\end{abstract}

\section{Introduction}

Adipose stem cells (ASCs) have the potential to differentiate into various cell phenotypes if there is a specific inducing microenvironment using suitable inductive substances [13]. Meanwhile, their abundance and relative ease of harvest, along with their autogenous immune-privileged status, have also made them an attractive candidate for tissue engineering and regenerative therapies $[4,5]$.

Tissue engineering enables the regeneration or repair of tissues and organs through combinations of stem cells, biomaterial scaffolds, and regulatory growth factors $[6,7]$. ASC-based tissue engineering strategies depend primarily on the quality of the ASC fraction used. Although a large number of studies have been conducted to assess the differentiation potential of ASCs in different carriers, there are still some unclear aspects regarding the basic knowledge of ASC biology and the clinical applications. These include the following: (i) What is the best definition for ASCs, and what is the true nature of the fractions of ASCs used by the various investigators? (ii) Does heterogeneity exist between freshly isolated ASCs and ASCs expanded in several culture passages? (iii) What are the best procedures for harvesting adipose tissue, preparing the stromal vascular fraction (SVF), and isolating ASCs? (iv) What are the best procedures for cell banking and cellular cryopreservation? The past few years have seen exciting progress in tissue engineering and regenerative medicine using various biomaterials and scaffold [8-11]. Natural and synthetic materials have been developed to provide a carrier scaffold that is ideally supposed to mimic the extracellular matrix (ECM) properties of an in vivo microenvironment to induce tissue formation $[12,13]$. Nowadays, the development of efficient biomaterials and scaffolds is still in high demand for the production of clinically useable volumes of new tissues to replace lost or malfunctioning body parts and to achieve uncomplicated wound healing.

It is crucial that scaffolding materials can positively interact with surrounding tissue to not only fill the defect, but also facilitate the natural regeneration of stem cells. Significant efforts have been made to develop such scaffolds for tissue engineering applications [14-16]. For example, electrospinning, lithography, microfabrication, and self-assembly techniques have been widely explored for the fabrication of engineered scaffolds appropriate for specific tissue applications. Considering the usage of these engineered scaffolds in the body, they should have the following characteristics: 
(i) possession of appropriate surface properties to promote the adhesion, proliferation, and differentiation of stem cells; (ii) low toxicity and immunogenicity; (iii) high porosity; and (iv) degradability that is adequate for specific tissues, with an interconnected pore network for cell growth and flow transport of nutrients and metabolic waste. The objective of this review is to recapitulate the progress in the fields of biomaterial and scaffold development and various procedures for ASC selection for tissue engineering applications and to review several clinical cases for the advancement of ASCsbased tissue engineering strategies.

\section{Basic Knowledge on the Biology of ASCs in Regenerative Medicine}

In the past decade, a number of cell characterization studies have described the underlying biology of ASCs [17-33]. Preclinical studies on the use of ASCs both in vitro and in vivo have been performed, and the efficacy of ASCs has been determined in several clinical trials [34-40]. Compared with bone marrow or umbilical cord stem cells, ASCs have a similar self-renewal ability in vitro, and the ability of ASCs to differentiate in other mesodermal and ectodermal lineages has been demonstrated on several occasions [1, 41-45]. Moreover, ASCs release multiple growth factors, such as the two key factors vascular endothelial growth factor (VEGF) and hepatocyte growth factor (HGF). Other factors include VEGF$\mathrm{B}, \mathrm{VEGF}-\mathrm{C}$, fibroblast growth factor- (FGF-) 2, angiopoietin(Ang-) 1, Ang-2, SPARC/osteonectin, platelet-derived growth factor- (PDGF-) b, transforming growth factor (TGF), and stromal cell-derived factor-1 (SDF-1) [46]. However, the specific population of ASCs with the greatest therapeutic potential remains unclear. Since the initial reports in the late 1960s [47], many researchers have established that stromal stem cells similar to those identified in bone marrow can be isolated from adipose tissue that is either resected as intact tissue or aspirated using tumescent liposuction [17, 48, 49]. In general, the obtained adipose tissue is digested with one of the following: collagenase, dispase, trypsin, or related enzymes. A consensus exists regarding temperature $\left(37^{\circ} \mathrm{C}\right)$, digestion duration times (range, $30 \mathrm{~min}$ to $>1 \mathrm{~h}$ ), and ratios of tissue weight to volume; however, protease concentrations are far more variable. Following the neutralization of the enzymes and differential centrifugation, the released elements, which are separated from the mature adipocytes, are defined as the SVF. The SVF consists of a heterogeneous mesenchymal population of cells that includes not only adipose stromal and hematopoietic stem and progenitor cells but also endothelial cells, erythrocytes, fibroblasts, lymphocytes, monocyte/macrophages, and pericytes $[17,50,51]$. For the phenotypic characterization of the SVF, the International Federation for Adipose Therapeutics and Science (IFATS) and the International Society for Cellular Therapy (ISCT) proposed a stromal cell population, excluding hematopoietic and endothelial cells, based on the following combination: CD45-CD235a-CD31-CD34+ and additional markers used to identify SVF are CD13 (APN), CD73 (L-VAP-2), CD90 (Thy-1), and CD105 (Endoglin). Based on the existing literature, this population combination represents at least $20 \%$ of the cells in the SVF [52-56], and the percentage of CD34+ cells mainly depends on the method used to harvest the adipose tissue, the degree of vascular hemorrhage, and the subsequent digestion and isolation techniques. In addition to the enzyme digestion, methods for isolating SVF cells using mechanical, nonenzymatic techniques have been developed recently, and some have been applied in clinical practice [5759].

When SVF pellets are seeded into culture, a subset of elongated cells begins to adhere to the bottom of the plastic tissue culture plate. After a combination of washing steps and culture expansion with media to remove most of the hematopoietic cell population from the SVF cells, these cells are purified as an adherent cell population termed ASCs. ASCs are less heterogeneous than SVF cells and have the ability to undergo self-renewal and the capacity to undergo multilineage differentiation and generate multiple terminally differentiated cells when cultured in specific lineage-inducing culture media. One main difference between SVF cells and ASC suspensions is the high percentage of CD45+ cells in the SVF cell population (30-70\%) and the low or undetectable percentage in ASC population (2-30\%). ASCs generally express CD34+ during the early phase of culture (within 812 population doublings after culture of the SVF), but then its expression decreases with continued cell division $[51,55]$. A joint statement by the IFATS and ISCT recommended that the surface antigens used to characterize ASCs should include CD73, CD90, and CD34 without CD45 and CD31. In addition, CD13 has also been proposed as an alternative or supplement to CD105 [17]. To date, most experimental research groups have isolated ASCs by tissue digestion, centrifugation, and the capacity of ASCs to adhere to cell culture plastic surfaces $[9,43,60]$. However, the adherent cell population also contains other cell types that are not multipotential [61-63]. In order to overcome the problem of "contamination," a number of alternative methods have been proposed, including magnetic-activated cell sorting (MACS) and fluorescence-activated cell sorting (FACS). FACS is a typical cell enrichment method that utilizes complementary fluorochrome conjugated antibodies to label cells of interest. However, the sorted cells obtained from FACS can be utilized for diagnostic and experimental purposes but not for therapeutics due to problems with safety and efficacy [64, 65]. MACS is an antibody-aided technique based on immunomagnetic beads coated with specific antibodies against stem cell surface molecules, and it is technically accessible and affordable. From the view of clinical application, MACS with biodegradable magnetic beads wins over FACS on the grounds of safety, and it is the only method approved for use in clinical settings [61, 66-68].

Clinical research on adult stromal cell populations has accelerated, and multiple clinical investigations are underway to examine the use of ASCs and SVF cells for tissue engineering and regenerative medical applications $[22,69,70]$. To achieve the large numbers of ASCs required for clinical applications, either the cells need to be expanded in culture or ASCs must be pooled from multiple donors. Therefore, the development of stem cell banks is necessary. These banks must assure the quality and safety of these cell products, 
TABLE 1: Synthesis of synthetic materials for tissue engineering applications using ASCs.

\begin{tabular}{|c|c|c|c|}
\hline Materials & Properties & Principal uses & References \\
\hline $\mathrm{TiO}_{2}$ nanofiber & $\begin{array}{l}\text { High degree of crystallinity and } \\
\text { surface wettability }\end{array}$ & Bone tissue engineering & {$[85]$} \\
\hline $\begin{array}{l}\text { Poly(3-hydroxybutyrate-co- } \\
\text { hydroxyvalerate) (PHBV) } \\
\text { scaffold }\end{array}$ & $\begin{array}{l}\text { Good integration with the surrounding } \\
\text { tissue, stiff character, and degradability }\end{array}$ & Skin tissue engineering & {$[10]$} \\
\hline $\begin{array}{l}\text { Copolymer PEGylated fibrin (P-fibrin) } \\
\text { gels }\end{array}$ & $\begin{array}{l}\text { Stable urethane (carbamate) linkage, } \\
\text { degradability }\end{array}$ & $\begin{array}{l}\text { Cardiovascular and skin } \\
\text { tissue engineering }\end{array}$ & {$[91]$} \\
\hline $\begin{array}{l}\text { Poly(glycerol sebacate) } \\
\text { (PGS)/poly(L-lactic acid) (PLLA) } \\
\text { blend scaffolds }\end{array}$ & $\begin{array}{l}\text { Favorable porous microstructures, } \\
\text { good hydrophilicity, appropriate } \\
\text { mechanical properties for soft tissue } \\
\text { applications, and degradability }\end{array}$ & Adipose tissue engineering & {$[93]$} \\
\hline $\begin{array}{l}\text { Poly(lactic- } \\
\text { coglycolicacid)/multiwalled carbon } \\
\text { nanotubes/silk fibroin } \\
\text { (PLGA/MWCNTs/SF) nanofibrous } \\
\text { scaffolds }\end{array}$ & $\begin{array}{l}\text { Nonwoven structures and random } \\
\text { fiber distribution with smooth and } \\
\text { beadless fibers morphology }\end{array}$ & Nerve tissue engineering & {$[95]$} \\
\hline $\begin{array}{l}\text { Poly-D,L-lactic acid/polyethylene } \\
\text { glycol/poly-D,L-lactic acid } \\
\text { (PDLLA-PEG)]/hyaluronic acid (HA) } \\
\text { matrix }\end{array}$ & $\begin{array}{l}\text { Designed architectures, high } \\
\text { mechanical strength and } \\
\text { biodegradability, biocompatibility, and } \\
\text { water solubility }\end{array}$ & Cartilage tissue engineering & {$[99]$} \\
\hline
\end{tabular}

especially when the stored ASCs are intended for clinical use in cell therapy and regenerative medicine. Cryopreservation may be an ideal option for this and is currently the only method to preserve ASCs while maintaining their functional properties and genetic characteristics in the long term [71-73]. Slow freezing and vitrification are the currently available methods for the cryopreservation of stem cells in laboratories and clinics [74-78]. Vitrification only works well with the cryopreservation of human cells in small volumes, such as oocytes, but it is ill-suited for large volumes of ASCs [79, 80]. Moreover, vitrification techniques require higher cryoprotectant agent concentrations, which induces toxicity and osmotic stress in cells and tissues. Slow freezing is an established technique pioneered in the early $1970 \mathrm{~s}$ and involves cryopreserving biological samples at controlled freezing rates to avoid intracellular ice formation and minimize structural damage to the cell membrane and cytoskeleton $[81,82]$. Cryoprotectant agents are used at relatively low concentrations [21] in slow freezing, which has become the standard method for cell and tissue cryopreservation. However, formation of ice crystals, extreme hyperosmolarity, and dehydration are still reported when cells undergo the slow freezing process. Dimethyl sulfoxide (DMSO) is the most widely used cryopreservant for cells, but it is known to be toxic at room temperature. Trehalose is a nontoxic disaccharide of glucose that may stabilize and preserve cells and cellular structures during the freezing procedure. A cryopreservation method using trehalose as a cryoprotective agent is recommended for the long-term preservation of ASCs compared to simple cryopreservation or to cryopreservation using DMSO alone. Other cryoprotective agents such as polyvinylpyrrolidone and methylcellulose have been developed to replace DMSO; however, they are less efficient than DMSO in terms of maintaining ASC viability [75].
Adipose-derived stem cells are a promising cell source for regenerative medicine. It is important to understand the basic knowledge and biology behind stem cells, and further research is needed to guarantee the safety of ASCs and the effectiveness of tissue engineering using ASCs.

\section{Advancement in Synthetic Materials for Tissue Engineering Applications Using ASCs}

In the provision of an appropriate microenvironment for cellular components to interact with, the extracellular matrix (ECM) is an important component of normal tissue that must be considered. Various synthetic materials have been developed to provide carrier scaffolds that mimic ECM properties for tissue regeneration and reconstruction in combination with ASCs (Table 1). The advantages of synthetic materials and scaffolds rely on the technical possibility that chemical and physical properties (e.g., porosity, surface characteristics, and degradation products nature) can be specifically optimized for a particular application [83, 84]. Ideally, a polymeric material used for tissue engineering should be able to regulate cell proliferation without the loss of pluripotency and to direct differentiation into a specific cell lineage when desired. Tan et al. described the influence of $\mathrm{TiO}_{2}$ nanofibrous surface structures, which were produced in situ onto Ti-6Al$4 \mathrm{~V}$ substrate via a thermal oxidation process, on the regulation of proliferation and preservation of stemness of ASCs. The results show that ASCs exhibit better adhesion and significantly enhanced proliferation on $\mathrm{TiO}_{2}$ nanofibrous surfaces than on flat control surfaces, thus presenting a promising potential for the application of $\mathrm{TiO}_{2}$ nanofibrous surfaces in the field of bone tissue engineering and regenerative therapies [85]. Although much has been done to develop tissue-engineered skin substitutes in the past decade, poor visualization, 
hypertrophic scarring, and keloid formation are still possible negative outcomes for current skin graft strategies [86-88]. In an effort to overcome these limitations, Zonari et al. proposed the combination of poly(3-hydroxybutyrate-cohydroxyvalerate) (PHBV) structures with ASCs to induce skin regeneration in a full-thickness model. In this work, PHBV scaffolds demonstrated good integration with the surrounding tissue, allowing exudation and infiltration by inflammatory cells, which may contribute to rapid degradation over time. Furthermore, PHBV scaffolds offered a moist environment combined with a stiff character that withstands contraction and simultaneously stimulates the secretion of various growth factors by seeded ASCs; these factors enhance vascularization and ECM deposition with reduced scarring. Ultimately, this study revealed the great advantages of PHBV loaded with ASCs to improve wound healing and skin regeneration with reduced scarring in skin tissue engineering [10]. The advancement of tissue engineering as a regenerative therapy relies on rapid vascularization of tissue constructs, and engineered three-dimensional biomaterials are known to affect the angiogenic capacity of seeded stem cells [89-91]. Copolymer PEGylated fibrin (P-fibrin) gels were introduced by Chung et al. as an ASC-carrying scaffold for encouraging local angiogenesis in an in vitro culture model without added soluble factors. In P-fibrin gels, ASCs elicited higher von Willebrand factor expression than the two commonly used hydrogels (i.e., collagen and fibrin). After seven days of cultivation, vascular endothelial growth factor (VEGF) was secreted more in fibrin and P-fibrin gels than in collagen; several other angiogenic and immunomodulatory cytokines were similarly enhanced. Moreover, P-fibrin matrices were uniquely able to drive a vessel-like phenotype in ASCs and induce formation of well-organized vascular networks relative to other gels. Thus, it can be speculated that the research on ASCs' regenerative potential in a carrier scaffold can be expanded to include cardiovascular and skin tissue engineering applications based on the observed angiogenic properties of ASCs in P-fibrin [91]. Seeding cells on mechanically appropriate scaffolds and applying specific mechanical stimulation to these cells have been found to be beneficial in terms of proliferation and differentiation $[92,93]$. Frydrych et al. reported a large and flexible 3D porous poly(glycerol sebacate) (PGS)/poly(L-lactic acid) (PLLA) blend scaffold with mechanical properties comparable to adipose tissue that was fabricated via a freeze-drying and a subsequent curing process. In vitro cell test results provided clear evidence that PGS/PLLA scaffolds are suitable for the culture of ASCs, as they are characterized by deep cell penetration and ECM growth. This work demonstrates that the PGS/PLLA scaffolds provided favorable porous microstructures, good hydrophilic characteristics, and appropriate mechanical properties for soft tissue applications [93]. Neural tissue possesses a very limited capacity to regenerate new functional neurons after nerve injuries, and tissue-engineered neural tissues using stem cells may serve as a promising alternative for neural regeneration. However, such stem cells would need to proliferate and differentiate into the desired phenotype with the aid of adequate chemical, mechanical, or biological stimuli regeneration [94-96]. Catalpol is a natural active ingredient extracted from a traditional Chinese medicine. Guo et al. evaluated the effects of a catalpol-loaded scaffold on guiding the neuronal differentiation of hASCs. In their study, the process for catalpol loading into the electrospun poly(lacticcoglycolic acid)/multiwalled carbon nanotubes/silk fibroin (PLGA/MWCNTs/SF) nanofibrous scaffolds was successfully established. As a result of adding catalpol, the diameters of the nanofibers decreased and the porosity increased. Moreover, the mechanical properties of the composite scaffolds were improved, and more neuronal-like cells were found on scaffolds with catalpol [95]. The poor self-healing ability of cartilage necessitates the development of methods for cartilage regeneration. Fabrication of scaffolds with live stem cell incorporation and subsequent differentiation presents a promising route $[97,98]$. Sun et al. [99] reported the use of a visible-light-based PSL (VL-PSL) system to encapsulate hASCs into a biodegradable polymer [poly-D,Llactic acid/polyethylene glycol/poly-D,L-lactic acid (PDLLAPEG)]/hyaluronic acid (HA) matrix to produce live cell constructs with customized architectures. In the chondrogenic medium-treated group (TGF- $\beta 3$ group), hASCs showed high viability (84\%) and expressed the chondrogenic genes Sox9, collagen type II, and aggrecan at 11, 232, and $2.29 \times 10^{5}$ fold increases, respectively, compared to levels at day 0 in nonchondrogenic medium. After 28 days, the mechanical strength of the TGF- $\beta 3$ group remained high at $240 \mathrm{kPa}$. Thus, PSL and PDLLA-PEG/HA-based fabrication method using ASCs is a promising approach for producing mechanically competent engineered cartilage.

Thus, synthetic materials provide greater control over the mechanical and biochemical properties of the carrier scaffolds and represent a promising tool in tissue engineering and regeneration medicine [100].

\section{Development of Natural Materials for Tissue Engineering Applications Using ASCs}

In accordance with the plastic surgery rule of "replace with alike," natural materials have recently been recognized as an attractive choice for tissue engineering applications. Natural materials chosen for tissue engineering scaffolds are either compounds of the native ECM or polymers extracted from other biological systems $[12,101]$. Evidence indicates that natural materials can behave similar to the ECM and possess biocompatibility, biodegradability, and inherent biological functions that could make them suitable for a range of tissue engineering applications [102-105]. Over the past several years, a wide range of natural materials has become available for tissue engineering strategies (Table 2). Among them, decellularized extracellular matrix has received increasing attention [106-110]. During tissue decellularization, cells are discharged from tissues, but the native ultrastructure and composition of the ECM is highly preserved, which is expected to be able to direct the differentiation fate of the seeded stem cells [111]. The combined use of decellularized human adipose tissue extracellular matrix (hDAM) and human adipose-derived stem cells (hASCs) as an adipose tissue engineering strategy was first introduced by Wang et al. [12]. In this study, engineered fat grafts (hDAM combined 


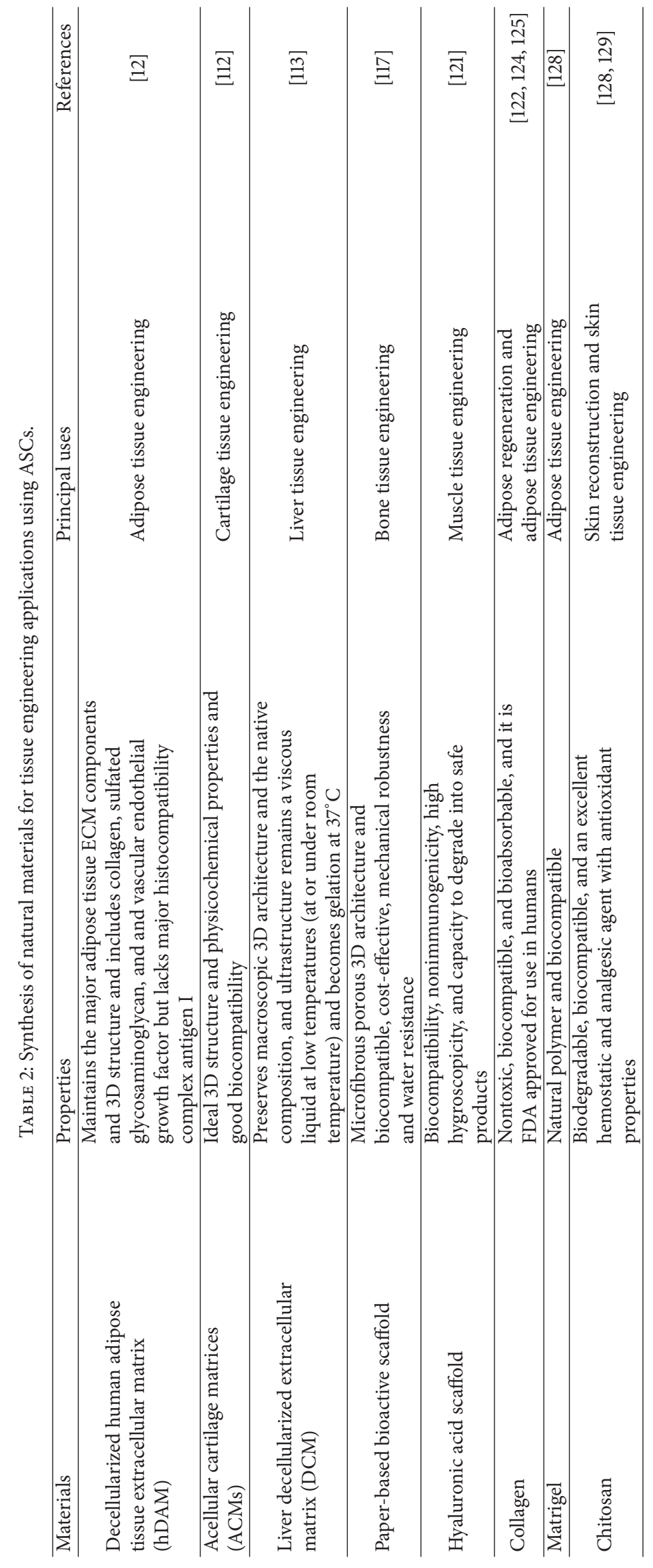


with hASCs) were implanted subcutaneously in nude rats. The results showed that hASCs seeded in hDAM contributed to adipose tissue formation; the implanted engineered fat grafts maintained their volume for eight weeks. Hence, this study provides a platform and novel scaffold design for adipose tissue engineering of hDAM-hASC constructs. Current cartilage tissue engineering technology has developed quickly and efforts have focused on the creation of a suitable chondrocyte scaffold. Acellular cartilaginous matrix (ACM), which is obtained from fresh cartilage using a series of acellular manipulations, is a recently developed natural matrix material. Wang et al. reported that the repair of articular cartilage defects had been achieved with ASCs and acellular cartilaginous matrix in rabbits [112]. In the tissueengineered cartilage group (ACM combined with ASCs) after 12 weeks, articular cartilage defects were filled with chondrocyte-like tissue with a smooth surface and were rich in glucan and type II collagen, similar to normal articular cartilage. Although the development of cartilage tissue engineering is still in its infancy, the acellular cartilaginous matrix obtained in this study offers tremendous potential in cartilage regeneration medicine. Recently, a decellularized liver $3 \mathrm{D}$ matrix scaffold has been proved to be able to facilitate the activity and function of the hepatic cells and stem cells [113-115]. Zhang and Dong [113] compared the hepatogenic differentiation-inducing effect of decellularized liver 3D matrix scaffold and several extracellular matrices, including collagen, fibronectin, and Matrigel in combination with mouse adipose-derived mesenchymal stem cells in vitro. The results clearly demonstrated that decellularized liver ECM gel, either on its own or in the presence of grow factors, could significantly enhance hepatic differentiation from ASCs compared with other matrix scaffolds; this demonstrates the feasibility of liver DCM as a bioscaffold for liver regenerative medicine and tissue engineering. Paper, which is produced from natural sources, can be supplied in large quantities with fair properties of biocompatibility and cost-effectiveness [116]. Hence, paper may have the potential in establishing tissue engineering scaffolds for therapeutic application of stem cells. Park et al. reported the feasibility of a paper-based bioactive scaffold for hASCs application to repair bone tissue defects for the first time [117]. In this study, paper scaffolds were prepared from three types of commercial paper materials: weighing paper (WP), chromatography paper (CP), and wiping tissue (WT), after which a polymercoating method called initiated chemical vapor deposition (iCVD) was employed to coat the paper scaffold to achieve favorable biochemical surface properties (e.g., adhesiveness and water resistance), without damaging the scaffolds. The results showed that osteogenic differentiation of hASCs was induced on the paper scaffolds under osteogenesis-inducing conditions in vivo, indicating that paper material possesses great potential as a bioactive, functional, and cost-effective natural scaffold for adipose stem cell-mediated bone tissue engineering. Insoluble (derivatized or crosslinked) forms of HA have been extensively investigated for tissue engineering purposes due to HA's role in the extracellular matrix as well as its biocompatibility, nonimmunogenicity, high hygroscopicity, and capacity to degrade into safe products [118-121].
Desiderio et al. evaluated the differentiation potential of constructs made from a new crosslinked HA (XHA) scaffold on which NG2+ ASCs were loaded. Thirty days after engraftment in mice, NG2+ ASCs underwent a complete myogenic differentiation and fabricated human skeletal muscle tissue, indicating a significant step in muscle regeneration without the need for a prior in vitro muscle differentiation step [121].

In summary, the application of natural materials in the field of regeneration medicine is currently progressing. The advantages of natural materials are biocompatibility and mechanical and biological properties consistent with in vivo features, making them perfect candidates for tissue engineering field. Apart from the neoteric materials mentioned above, other commonly used natural materials in tissue engineering include collagen [122-125], hyaluronan [126], Matrigel [127, 128], and chitosan [129].

\section{Clinical Applications of Different Carrier Scaffolds in Combination with ASCs in Tissue Engineering Strategies}

The major role of regenerative medicine in this century is based on cell therapy, in which ASCs hold a key position [130-135]. Recently, a number of in vitro and a few in vivo studies using ASCs in combination with carrier scaffolds can be found through searches and on clinical trial websites. However, the use of cultured stem cells in clinical settings is strictly controlled by governmental regulations around the world, which largely restrict the application of ASCs in regenerative medicine. Meanwhile, plastic surgeons in Korea and Japan have played a leading role in pioneering the use of ASCs in tissue engineering more than any other Western nations due to less stringent government regulations.

It is well known that diabetic ulcers and chronic radiation ulcers are notorious for their recurrence, or failure to heal due to patient debilitation or poor local blood supply conditions. Several conventional reconstructive surgeries have been introduced for patients with chronic nonhealing cutaneous lesions $[136,137]$. Presently, Kim and Jeong reported a less invasive method using adipose stem cell-based therapy and a collagen sponge scaffold, which was covered with an artificial dermis (Terudermis ${ }^{\circledast}$ ) to deal with a chronic diabetic ulcer on the knee area. Two weeks after application, vascular tissue ingrowth was seen in the lesion area and thus a skin graft could be placed on the newly engineered vascular bed [5]. Complex fistulas are difficult to manage. Currently limited surgical procedures often result in high recurrence rates, whereas extensive surgical procedures may cause fecal incontinence. One recent improvement in treating complex fistulas may be the use of ASCs in combination with a fibrin glue scaffold described by Garcia-Olmo et al. [138]. The fibrin glue used in this study contained human fibrinogen, bovine aprotinin, and human thrombin, and the ASCs were isolated from lipoaspirated fat tissue. Eight weeks after the final treatment, fistula healing was observed in 17 (71 percent) of 24 patients who received fibrin glue plus ASCs, in comparison to 4 (16 percent) of 25 patients who received fibrin glue alone. The proportion of patients with 
healing strongly indicates that the combination of the fibrin glue scaffold and ASCs is an effective and safe treatment for complex perianal fistulas. Autogenous bone graft has been considered to be the gold standard for reconstructive bone surgery. However, harvesting bone for grafting is associated with significant donor site morbidity that requires additional operative and anesthetic time [139]. An alternative approach is bone tissue engineering, through which in situ bone formation by using combinations of biomaterials, bioactive molecules, and stem cells can be achieved [140, 141]. Sandor et al. reported a case that used an ASC tissue-engineered construct to treat a large anterior mandibular defect. In this report, expanded ASCs were seeded on $\beta$-tricalcium phosphate $(\beta$-TCP) granular scaffolds consisting of recombinant human bone morphogenetic protein-2; the constructs were implanted into a U-shaped titanium mesh that spanned the parasymphyseal defect. Ten months after reconstruction, dental implants were integrated into the grafted site successfully with a dental implant-supported overdenture. The patient has been followed for three years since the tissueengineered constructs were placed; he has been pleased with the aesthetic outcome of the procedure and continues to be satisfied with the function of his dental implants.

Although the applications of scaffolding materials together with ASCs technologies are a rapidly developing field of regeneration medicine, they are highly experimental so far. Thus, there still remains a significant need to develop efficient carrier materials that may bridge the gap and lead towards clinical applications in tissue engineering.

\section{Conclusions and Future Perspectives}

In the past several years, evidence has demonstrated that the ECM not only offers structural support for cells but also profoundly influences the major cellular programs of growth, differentiation, and apoptosis [142, 143]. An ideal scaffold structure must accomplish the roles of the extracellular matrix for the seeded cells, which will be used to form a tissue-engineered construct and to promote the repair/regeneration of damaged tissue $[144,145]$. Hence, the design of carrier materials that can regulate cell behaviors such as proliferation and differentiation is the main purpose for the fabrication of tissue engineering scaffolds. Moreover, we should begin to understand that biomaterials and scaffolds used in tissue engineering strategies are dynamic, mobile, and multifunctional regulators of cellular behavior, and not just mere carriers for stem cells or storehouses for cytokines. Indeed, as the field of tissue engineering is still in its infancy, possible biomechanics and biomechanical effects created by different types of scaffolds on seeded ASCs should be further elucidated so that carrier scaffolds with special properties can be created. The creation of such scaffolds would help us to optimize cellular activities including changes in morphology, proliferation, and differentiation.

In general, carrier materials for the successful generation and maintenance of engineered tissue constructs should have several necessary properties including biocompatibility, degradability, low toxicity, and immunogenicity. However, most carrier scaffolds possess only some of these desirable properties. If a scaffold could embody all of these properties successfully, it would provide an ideal platform for tissue regeneration.

In conclusion, ASCs have a prominent and strong role in tissue engineering and regenerative medicine due to their high cell yield in adipose tissue, their ability to differentiate into multiple lineages and secrete various cytokines, and their immunomodulatory effects. The field of ASCs-based tissue engineering therapy is still young. Ongoing and future development of carrier scaffolds together with reasonable promotion of stem cell research and clinical studies will no doubt gradually bring ASC-based tissue engineering technology down from the ivory tower and make it clinically accessible on a larger scale, thereby benefiting more patients.

\section{Conflict of Interests}

The authors confirm that there is no known conflict of interests associated with this paper.

\section{Acknowledgments}

The authors gratefully thank Feng Lu for his support and contribution during the conducting of this study. This work was supported by the National Natural Science Foundation of China (81471881, 81372083, 81171834, and 81201482), Key Clinical Specialty Discipline Construction Program, and Health Collaborative Innovation Major Projects of Guangzhou (7414275040815).

\section{References}

[1] E. Anghileri, S. Marconi, A. Pignatelli et al., "Neuronal differentiation potential of human adipose-derived mesenchymal stem cells," Stem Cells and Development, vol. 17, no. 5, pp. 909-916, 2008.

[2] D. A. Young, Y. S. Choi, A. J. Engler, and K. L. Christman, "Stimulation of adipogenesis of adult adipose-derived stem cells using substrates that mimic the stiffness of adipose tissue," Biomaterials, vol. 34, no. 34, pp. 8581-8588, 2013.

[3] B. F. Seo, K. J. Kim, M. K. Kim, and J. W. Rhie, "The effects of human keratinocyte coculture on human adipose-derived stem cells," International Wound Journal, 2014.

[4] D.-C. Yeh, T.-M. Chan, H.-J. Harn et al., "Adipose tissue-derived stem cells in neural regenerative medicine," Cell Transplantation, vol. 24, no. 3, pp. 487-492, 2015.

[5] Y.-J. Kim and J.-H. Jeong, "Clinical application of adipose stem cells in plastic surgery," Journal of Korean Medical Science, vol. 29, no. 4, pp. 462-467, 2014.

[6] S. Giannitelli, P. Mozetic, M. Trombetta, and A. Rainer, "Combined additive manufacturing approaches in tissue engineering," Acta Biomaterialia, vol. 24, pp. 1-11, 2015.

[7] K. H. Moon, I. K. Ko, J. J. Yoo, and A. Atala, "Kidney diseases and tissue engineering," Methods, 2015.

[8] B. Ozcelik, A. Blencowe, J. Palmer et al., "Highly porous and mechanically robust polyester poly(ethylene glycol) sponges as implantable scaffolds," Acta Biomaterialia, vol. 10, no. 6, pp. 2769-2780, 2014. 
[9] F. M. Ghorbani, B. Kaffashi, P. Shokrollahi, E. Seyedjafari, and A. Ardeshirylajimi, "PCL/chitosan/Zn-doped nHA electrospun nanocomposite scaffold promotes adipose derived stem cells adhesion and proliferation," Carbohydrate Polymers, vol. 118, pp. 133-142, 2015.

[10] A. Zonari, T. M. Martins, A. C. Paula et al., "Polyhydroxybutyrate-co-hydroxyvalerate structures loaded with adipose stem cells promote skin healing with reduced scarring," Acta Biomaterialia, vol. 17, pp. 170-181, 2015.

[11] Y. Açil, X. Zhang, T. Nitsche et al., "Effects of different scaffolds on rat adipose tissue derived stroma cells," Journal of CranioMaxillo-Facial Surgery, vol. 42, no. 6, pp. 825-834, 2014.

[12] L. Wang, J. A. Johnson, Q. Zhang, and E. K. Beahm, "Combining decellularized human adipose tissue extracellular matrix and adipose-derived stem cells for adipose tissue engineering," Acta Biomaterialia, vol. 9, no. 11, pp. 8921-8931, 2013.

[13] M. Tallawi, E. Rosellini, N. Barbani et al., "Strategies for the chemical and biological functionalization of scaffolds for cardiac tissue engineering: a review," Journal of the Royal Society Interface, vol. 12, no. 108, 2015.

[14] J. Liao, K. Shi, Q. Ding, Y. Qu, F. Luo, and Z. Qian, "Recent developments in scaffold-guided cartilage tissue regeneration," Journal of Biomedical Nanotechnology, vol. 10, no. 10, pp. 30853104, 2014.

[15] L. Ghasemi-Mobarakeh, M. P. Prabhakaran, L. Tian et al., "Structural properties of scaffolds: crucial parameters towards stem cells differentiation," World Journal of Stem Cells, vol. 7, no. 4, pp. 728-744, 2015.

[16] N. Shadjou and M. Hasanzadeh, "Bone tissue engineering using silica-based mesoporous nanobiomaterials: recent progress," Materials Science and Engineering C: Materials for Biological Applications, vol. 55, pp. 401-409, 2015.

[17] P. Bourin, B. A. Bunnell, L. Casteilla et al., "Stromal cells from the adipose tissue-derived stromal vascular fraction and culture expanded adipose tissue-derived stromal/stem cells: a joint statement of the International Federation for Adipose Therapeutics and Science (IFATS) and the International Society for Cellular Therapy (ISCT)," Cytotherapy, vol. 15, no. 6, pp. 641648, 2013.

[18] N. Pallua and B. S. Kim, "Commentary on: interaction between breast cancer cells and adipose tissue cells derived from fat grafting," Aesthetic Surgery Journal, 2015.

[19] N. Pallua, M. Serin, and T. P. Wolter, "Characterisation of angiogenetic growth factor production in adipose tissuederived mesenchymal cells," Journal of Plastic Surgery and Hand Surgery, vol. 48, no. 6, pp. 412-416, 2014.

[20] A. Schellenberg, T. Stiehl, P. Horn et al., "Population dynamics of mesenchymal stromal cells during culture expansion," Cytotherapy, vol. 14, no. 4, pp. 401-411, 2012.

[21] D. Cholewa, T. Stieh, A. Schellenberg et al., "Expansion of adipose mesenchymal stromal cells is affected by human platelet lysate and plating density," Cell Transplantation, vol. 20, no. 9, pp. 1409-1422, 2011.

[22] F. De Francesco, G. Ricci, F. D’Andrea, G. F. Nicoletti, and G. A. Ferraro, "Human adipose stem cells: from bench to bedside," Tissue Engineering Part B: Reviews, vol. 21, no. 6, pp. 572-584, 2015.

[23] A. De Rosa, F. De Francesco, V. Tirino et al., "A new method for cryopreserving adipose-derived stem cells: an attractive and suitable large-scale and long-term cell banking technology," Tissue Engineering Part C: Methods, vol. 15, no. 4, pp. 659-667, 2009.
[24] F. De Francesco, V. Tirino, V. Desiderio et al., "Human CD $34^{+} /$ $\mathrm{CD}^{+} 0^{+} \mathrm{ASC}$ are capable of growing as sphere clusters, producing high levels of VEGF and forming capillaries," PLOS ONE, vol. 4, no. 8, Article ID e6537, 2009.

[25] F. D’Andrea, F. De Francesco, G. A. Ferraro et al., "Largescale production of human adipose tissue from stem cells: a new tool for regenerative medicine and tissue banking," Tissue Engineering -Part C: Methods, vol. 14, no. 3, pp. 233-242, 2008.

[26] M. Tobita, S. Tajima, and H. Mizuno, "Adipose tissue-derived mesenchymal stem cells and platelet-rich plasma: stem cell transplantation methods that enhance stemness," Stem Cell Research \& Therapy, vol. 6, article 215, 2015.

[27] Y. Shingyochi, H. Orbay, and H. Mizuno, "Adipose-derived stem cells for wound repair and regeneration," Expert Opinion on Biological Therapy, vol. 15, no. 9, pp. 1285-1292, 2015.

[28] F. Josh, M. Tobita, R. Tanaka et al., "Concentration of PDGF$\mathrm{AB}, \mathrm{BB}$ and TGF- $\beta 1$ as valuable human serum parameters in adipose-derived stem cell proliferation," Journal of Nippon Medical School, vol. 80, no. 2, pp. 140-147, 2013.

[29] H. Orbay, M. Tobita, and H. Mizuno, "Mesenchymal stem cells isolated from adipose and other tissues: basic biological properties and clinical applications," Stem Cells International, vol. 2012, Article ID 461718, 9 pages, 2012.

[30] H. Mizuno, M. Tobita, and A. C. Uysal, "Concise review: adipose-derived stem cells as a novel tool for future regenerative medicine," Stem Cells, vol. 30, no. 5, pp. 804-810, 2012.

[31] M. Tobita, H. Orbay, and H. Mizuno, "Adipose-derived stem cells: current findings and future perspectives," Discovery Medicine, vol. 11, no. 57, pp. 160-170, 2011.

[32] H. Mizuno, "Adipose-derived stem and stromal cells for cellbased therapy: current status of preclinical studies and clinical trials," Current Opinion in Molecular Therapeutics, vol. 12, no. 4, pp. 442-449, 2010.

[33] S. Tajima, M. Tobita, H. Orbay, H. Hyakusoku, and H. Mizuno, "Direct and indirect effects of a combination of adipose-derived stem cells and platelet-rich plasma on bone regeneration," Tissue Engineering Part A, vol. 21, no. 5-6, pp. 895-905, 2015.

[34] S. Bohr, H. O. Rennekampff, and N. Pallua, "Cell-enriched lipoaspirate arthroplasty: a novel approach to first carpometacarpal joint arthritis," Hand Surgery, vol. 20, no. 3, pp. 479481, 2015.

[35] P. J. Díaz-Agero Álvarez, Y. A. Bellido-Reyes, J. G. SánchezGirón, D. García-Olmo, and M. García-Arranz, "Novel bronchoscopic treatment for bronchopleural fistula using adiposederived stromal cells," Cytotherapy, vol. 18, no. 1, pp. 36-40, 2016.

[36] R. Sanz-Baro, M. Garcia-Arranz, H. Guadalajara, P. de la Quintana, M. D. Herreros, and D. Garcia-Olmo, "First-inhuman case study: pregnancy in women with Crohn's perianal fistula treated with adipose-derived stem cells: a safety study," Stem Cells Translational Medicine, vol. 4, no. 6, pp. 598-602, 2015.

[37] F. de la Portilla, F. Alba, D. García-Olmo, J. M. Herrerías, F. X. González, and A. Galindo, "Expanded allogeneic adiposederived stem cells (eASCs) for the treatment of complex perianal fistula in Crohn's disease: results from a multicenter phase I/IIa clinical trial," International Journal of Colorectal Disease, vol. 28, no. 3, pp. 313-323, 2013.

[38] T. Georgiev-Hristov, M. García-Arranz, and D. García-Olmo, "Adipose tissue-derived products for complex fistula treatment," Techniques in Coloproctology, vol. 17, no. 6, pp. 675-676, 2013. 
[39] H. Guadalajara, D. Herreros, P. De-La-Quintana, J. Trebol, M. Garcia-Arranz, and D. Garcia-Olmo, "Long-term follow-up of patients undergoing adipose-derived adult stem cell administration to treat complex perianal fistulas," International Journal of Colorectal Disease, vol. 27, no. 5, pp. 595-600, 2012.

[40] M. D. Herreros, M. Garcia-Arranz, H. Guadalajara, P. DeLa-Quintana, and D. Garcia-Olmo, "Autologous expanded adipose-derived stem cells for the treatment of complex cryptoglandular perianal fistulas: a phase III randomized clinical trial (FATT 1: fistula advanced therapy trial 1) and long-term evaluation," Diseases of the Colon \& Rectum, vol. 55, no. 7, pp. 762-772, 2012.

[41] C. Romagnoli and M. L. Brandi, "Adipose mesenchymal stem cells in the field of bone tissue engineering," World Journal of Stem Cells, vol. 6, no. 2, pp. 144-152, 2014.

[42] J.-P. Stromps, N. E. Paul, B. Rath, M. Nourbakhsh, J. Bernhagen, and N. Pallua, "Chondrogenic differentiation of human adipose-derived stem cells: a new path in articular cartilage defect management?" BioMed Research International, vol. 2014, Article ID 740926, 7 pages, 2014.

[43] T. T. Han, S. Toutounji, B. G. Amsden, and L. E. Flynn, "Adiposederived stromal cells mediate in vivo adipogenesis, angiogenesis and inflammation in decellularized adipose tissue bioscaffolds," Biomaterials, vol. 72, pp. 125-137, 2015.

[44] F. Colazzo, F. Alrashed, P. Saratchandra et al., "Shear stress and VEGF enhance endothelial differentiation of human adiposederived stem cells," Growth Factors, vol. 32, no. 5, pp. 139-149, 2014.

[45] J. M. Lasso, R. Pérez Cano, Y. Castro, L. Arenas, J. García, and M. E. Fernández-Santos, "Xenotransplantation of human adiposederived stem cells in the regeneration of a rabbit peripheral nerve," Journal of Plastic, Reconstructive \& Aesthetic Surgery, vol. 68, no. 12, pp. e189-e197, 2015.

[46] Q. Chang and F. Lu, "A novel strategy for creating a large amount of engineered fat tissue with an axial vascular pedicle and a prefabricated scaffold," Medical Hypotheses, vol. 79, no. 2, pp. 267-270, 2012.

[47] C. H. Hollenberg and A. Vost, "Regulation of DNA synthesis in fat cells and stromal elements from rat adipose tissue," The Journal of Clinical Investigation, vol. 47, no. 11, pp. 2485-2498, 1969.

[48] J. M. Gimble, A. J. Katz, and B. A. Bunnell, "Adipose-derived stem cells for regenerative medicine," Circulation Research, vol. 100, no. 9, pp. 1249-1260, 2007.

[49] A. S. Zanetti, C. Sabliov, J. M. Gimble, and D. J. Hayes, "Human adipose-derived stem cells and three-dimensional scaffold constructs: a review of the biomaterials and models currently used for bone regeneration," Journal of Biomedical Materials Research Part B: Applied Biomaterials, vol. 101, no. 1, pp. 187-199, 2013.

[50] W. P. Cawthorn, E. L. Scheller, and O. A. MacDougald, "Adipose tissue stem cells meet preadipocyte commitment: going back to the future," Journal of Lipid Research, vol. 53, no. 2, pp. 227-246, 2012.

[51] J. B. Mitchell, K. McIntosh, S. Zvonic et al., "Immunophenotype of human adipose-derived cells: temporal changes in stromalassociated and stem cell-associated markers," Stem Cells, vol. 24, no. 2, pp. 376-385, 2006.

[52] V. Planat-Benard, J.-S. Silvestre, B. Cousin et al., "Plasticity of human adipose lineage cells toward endothelial cells: physiological and therapeutic perspectives," Circulation, vol. 109, no. 5, pp. 656-663, 2004.
[53] G. Pachón-Peña, G. Yu, A. Tucker et al., "Stromal stem cells from adipose tissue and bone marrow of age-matched female donors display distinct immunophenotypic profiles," Journal of Cellular Physiology, vol. 226, no. 3, pp. 843-851, 2011.

[54] C. Sengenès, K. Lolmède, A. Zakaroff-Girard, R. Busse, and A. Bouloumié, "Preadipocytes in the human subcutaneous adipose tissue display distinct features from the adult mesenchymal and hematopoietic stem cells," Journal of Cellular Physiology, vol. 205, no. 1, pp. 114-122, 2005.

[55] M. Maumus, J.-A. Peyrafitte, R. D’Angelo et al., "Native human adipose stromal cells: localization, morphology and phenotype," International Journal of Obesity, vol. 35, no. 9, pp. 1141-1153, 2011.

[56] F. Lanza, L. Healy, and D. R. Sutherland, "Structural and functional features of the CD34 antigen: an update," Journal of Biological Regulators and Homeostatic Agents, vol. 15, no. 1, pp. $1-13,2001$.

[57] M. T. Friji, "Nanofat grafting: basic research and clinical applications," Plastic and Reconstructive Surgery, vol. 134, no. 2, pp. 333e-334e, 2014.

[58] O. Memar, A. Nezamabadi, B. Y. Milani, F. Y. Milani, and A. Djalilian, "Nanofat grafting: basic research and clinical application," Plastic and Reconstructive Surgery, vol. 133, no. 5, article 728e, 2014.

[59] P. Tonnard, A. Verpaele, G. Peeters, M. Hamdi, M. Cornelissen, and H. Declercq, "Nanofat grafting: basic research and clinical applications," Plastic and Reconstructive Surgery, vol. 132, no. 4, pp. 1017-1026, 2013.

[60] P. A. Zuk, M. Zhu, H. Mizuno et al., "Multilineage cells from human adipose tissue: implications for cell-based therapies," Tissue Engineering, vol. 7, no. 2, pp. 211-228, 2001.

[61] M. Gierloff, L. Petersen, H.-H. Oberg, E. S. Quabius, J. Wiltfang, and Y. Açil, "Adipogenic differentiation potential of rat adipose tissue-derived subpopulations of stromal cells," Journal of Plastic, Reconstructive \& Aesthetic Surgery, vol. 67, no. 10, pp. 14271435, 2014.

[62] S. S. Tholpady, R. Llull, R. C. Ogle, J. P. Rubin, J. W. Futrell, and A. J. Katz, "Adipose tissue: stem cells and beyond," Clinics in Plastic Surgery, vol. 33, no. 1, pp. 55-62, 2006.

[63] N. Quarto and M. T. Longaker, "FGF-2 inhibits osteogenesis in mouse adipose tissue-derived stromal cells and sustains their proliferative and osteogenic potential state," Tissue Engineering, vol. 12, no. 6, pp. 1405-1418, 2006.

[64] R. W. Mays, W. Van’t Hof, A. E. Ting, R. Perry, and R. Deans, "Development of adult pluripotent stem cell therapies for ischemic injury and disease," Expert Opinion on Biological Therapy, vol. 7, no. 2, pp. 173-184, 2007.

[65] M. Mimeault, R. Hauke, and S. K. Batra, "Stem cells: a revolution in therapeutics-recent advances in stem cell biology and their therapeutic applications in regenerative medicine and cancer therapies," Clinical Pharmacology \& Therapeutics, vol. 82, no. 3, pp. 252-264, 2007.

[66] H. Valli, M. Sukhwani, S. L. Dovey et al., "Fluorescence- and magnetic-activated cell sorting strategies to isolate and enrich human spermatogonial stem cells," Fertility and Sterility, vol. 102, no. 2, pp. 566-580, 2014.

[67] S. Indumathi, R. Mishra, R. Harikrishnan, J. S. Rajkumar, N. Kantawala, and M. Dhanasekaran, "Lineage depletion of stromal vascular fractions isolated from human adipose tissue: a novel approach towards cell enrichment technology," Cytotechnology, vol. 66, no. 2, pp. 219-228, 2014. 
[68] S. Miltenyi, W. Muller, W. Weichel, and A. Radbruch, "High gradient magnetic cell separation with MACS," Cytometry, vol. 11, no. 2, pp. 231-238, 1990.

[69] L. Casteilla, V. Planat-Benard, P. Laharrague, and B. Cousin, "Adipose-derived stromal cells: their identity and uses in clinical trials, an update," World Journal of Stem Cells, vol. 3, no. 4, pp. 25-33, 2011.

[70] M. Locke, V. Feisst, and S. Meidinger, "From bench to bedside: use of human adipose-derived stem cells," Stem Cells and Cloning: Advances and Applications, vol. 8, pp. 149-162, 2015.

[71] O. G. Davies, A. J. Smith, P. R. Cooper, R. M. Shelton, and B. A. Scheven, "The effects of cryopreservation on cells isolated from adipose, bone marrow and dental pulp tissues," Cryobiology, vol. 69, no. 2, pp. 342-347, 2014.

[72] K. W. Yong, B. Pingguan-Murphy, F. Xu et al., "Phenotypic and functional characterization of long-term cryopreserved human adipose-derived stem cells," Scientific Reports, vol. 5, article 9596, 2015.

[73] K. W. Yong, W. S. W. K. Zaman, F. Xu et al., "Cryopreservation of human mesenchymal stem cells for clinical applications: current methods and challenges," Biopreservation and Biobanking, vol. 13, no. 4, pp. 231-239, 2015.

[74] G. Liu, H. Zhou, Y. Li et al., "Evaluation of the viability and osteogenic differentiation of cryopreserved human adiposederived stem cells," Cryobiology, vol. 57, no. 1, pp. 18-24, 2008.

[75] S. Thirumala, J. M. Gimble, and R. V. Devireddy, "Evaluation of methylcellulose and dimethyl sulfoxide as the cryoprotectants in a serum-free freezing media for cryopreservation of adiposederived adult stem cells," Stem Cells and Development, vol. 19, no. 4, pp. 513-522, 2010.

[76] S. Thirumala, X. Wu, J. M. Gimble, and R. V. Devireddy, "Evaluation of polyvinylpyrrolidone as a cryoprotectant for adipose tissue-derived adult stem cells," Tissue Engineering-Part C: Methods, vol. 16, no. 4, pp. 783-792, 2010.

[77] E. A. Ozudogru and E. Kaya, "Cryopreservation of Thymus cariensis and T. vulgaris shoot tips: comparison of three vitrification-based methods," Cryo-Letters, vol. 33, no. 5, pp. 363-375, 2012.

[78] Y. Li, J.-C. Tan, and L.-S. Li, "Comparison of three methods for cryopreservation of human embryonic stem cells," Fertility and Sterility, vol. 93, no. 3, pp. 999-1005, 2010.

[79] Y. S. Song, D. Adler, F. Xu et al., "Vitrification and levitation of a liquid droplet on liquid nitrogen," Proceedings of the National Academy of Sciences of the United States of America, vol. 107, no. 10, pp. 4596-4600, 2010.

[80] X. Zhang, P. N. Catalano, U. A. Gurkan, I. Khimji, and U. Demirci, "Emerging technologies in medical applications of minimum volume vitrification," Nanomedicine, vol. 6, no. 6, pp. 1115-1129, 2011.

[81] P. Desrosiers, C. Légaré, P. Leclerc, and R. Sullivan, "Membranous and structural damage that occur during cryopreservation of human sperm may be time-related events," Fertility and Sterility, vol. 85, no. 6, pp. 1744-1752, 2006.

[82] J. Boldt, N. Tidswell, A. Sayers, R. Kilani, and D. Cline, "Human oocyte cryopreservation: 5-year experience with a sodiumdepleted slow freezing method," Reproductive BioMedicine Online, vol. 13, no. 1, pp. 96-100, 2006.

[83] J. F. FitzGerald and A. S. Kumar, "Biologic versus synthetic mesh reinforcement: what are the pros and cons?" Clinics in Colon and Rectal Surgery, vol. 27, no. 4, pp. 140-148, 2014.
[84] J. Znaleziona, P. Ginterová, J. Petr et al., "Determination and identification of synthetic cannabinoids and their metabolites in different matrices by modern analytical techniques-a review," Analytica Chimica Acta, vol. 874, pp. 11-25, 2015.

[85] A. W. Tan, L. Tay, K. H. Chua, R. Ahmad, S. A. Akbar, and B. Pingguan-Murphy, "Proliferation and stemness preservation of human adipose-derived stem cells by surface-modified in situ $\mathrm{TiO}_{2}$ nanofibrous surfaces," International Journal of Nanomedicine, vol. 9, no. 1, pp. 5389-5401, 2014.

[86] H. Lagus, M. Sarlomo-Rikala, T. Bohling, and J. Vuola, "Prospective study on burns treated with Integra", a cellulose sponge and split thickness skin graft: comparative clinical and histological study—randomized controlled trial," Burns, vol. 39, no. 8, pp. 1577-1587, 2013.

[87] S. Aarabi, M. T. Longaker, and G. C. Gurtner, "Hypertrophic scar formation following burns and trauma: new approaches to treatment," PLoS Medicine, vol. 4, no. 9, article e234, 2007.

[88] W. Haslik, L.-P. Kamolz, G. Nathschläger, H. Andel, G. Meissl, and M. Frey, "First experiences with the collagen-elastin matrix matriderm as a dermal substitute in severe burn injuries of the hand," Burns, vol. 33, no. 3, pp. 364-368, 2007.

[89] S. Levenberg, J. Rouwkema, M. Macdonald et al., "Engineering vascularized skeletal muscle tissue," Nature Biotechnology, vol. 23, no. 7, pp. 879-884, 2005.

[90] S. Natesan, G. Zhang, D. G. Baer, T. J. Walters, R. J. Christy, and L. J. Suggs, "A bilayer construct controls adipose-derived stem cell differentiation into endothelial cells and pericytes without growth factor stimulation," Tissue Engineering_Part A, vol. 17, no. 7-8, pp. 941-953, 2011.

[91] E. Chung, J. A. Rytlewski, A. G. Merchant, K. S. Dhada, E. W. Lewis, and L. J. Suggs, "Fibrin-based 3D matrices induce angiogenic behavior of adipose-derived stem cells," Acta Biomaterialia, vol. 17, pp. 78-88, 2015.

[92] P. M. Crapo and Y. Wang, "Physiologic compliance in engineered small-diameter arterial constructs based on an elastomeric substrate," Biomaterials, vol. 31, no. 7, pp. 1626-1635, 2010.

[93] M. Frydrych, S. Román, S. MacNeil, and B. Chen, "Biomimetic poly(glycerol sebacate)/poly(l-lactic acid) blend scaffolds for adipose tissue engineering," Acta Biomaterialia, vol. 18, pp. 4049, 2015.

[94] I. Faravelli, M. Bucchia, P. Rinchetti et al., "Motor neuron derivation from human embryonic and induced pluripotent stem cells: experimental approaches and clinical perspectives," Stem Cell Research and Therapy, vol. 5, no. 4, article 87, 2014.

[95] J. H. Guo, Y. Liu, Z. J. Lv et al., "Potential neurogenesis of human adipose-derived stem cells on electrospun catalpol-loaded composite nanofibrous scaffolds," Annals of Biomedical Engineering, vol. 43, no. 10, pp. 2597-2608, 2015.

[96] S. Sahoo, L. T. Ang, J. C.-H. Goh, and S.-L. Toh, "Growth factor delivery through electrospun nanofibers in scaffolds for tissue engineering applications," Journal of Biomedical Materials Research Part A, vol. 93, no. 4, pp. 1539-1550, 2010.

[97] R. S. Tuan, A. F. Chen, and B. A. Klatt, "Cartilage regeneration," The Journal of the American Academy of Orthopaedic Surgeons, vol. 21, no. 5, pp. 303-311, 2013.

[98] M. Demoor, D. Ollitrault, T. Gomez-Leduc et al., "Cartilage tissue engineering: molecular control of chondrocyte differentiation for proper cartilage matrix reconstruction," Biochimica et Biophysica Acta, vol. 1840, no. 8, pp. 2414-2440, 2014.

[99] A. X. Sun, H. Lin, A. M. Beck, E. J. Kilroy, and R. S. Tuan, "Projection stereolithographic fabrication of human adipose stem 
cell-incorporated biodegradable scaffolds for cartilage tissue engineering," Frontiers in Bioengineering and Biotechnology, vol. 3, article 115, 2015.

[100] M. Hosseinkhani, D. Mehrabani, M. H. Karimfar, S. Bakhtiyari, A. Manafi, and R. Shirazi, "Tissue engineered scaffolds in regenerative medicine," World Journal of Plastic Surgery, vol. 3, no. 1, pp. 3-7, 2014.

[101] M. Wang and L. Yu, "Transplantation of adipose-derived stem cells combined with decellularized cartilage ECM: a novel approach to nasal septum perforation repair," Medical Hypotheses, vol. 82, no. 6, pp. 781-783, 2014.

[102] X. Liu, J. M. Holzwarth, and P. X. Ma, "Functionalized synthetic biodegradable polymer scaffolds for tissue engineering," Macromolecular Bioscience, vol. 12, no. 7, pp. 911-919, 2012.

[103] Y. Li, H. Meng, Y. Liu, and B. P. Lee, "Fibrin gel as an injectable biodegradable scaffold and cell carrier for tissue engineering," The Scientific World Journal, vol. 2015, Article ID 685690, 10 pages, 2015.

[104] E. Taghiabadi, S. Nasri, S. Shafieyan, S. J. Firoozinezhad, and N. Aghdami, "Fabrication and characterization of spongy denuded amniotic membrane based scaffold for tissue engineering," Cell Journal, vol. 16, no. 4, pp. 476-487, 2015.

[105] E. Hosseinzadeh, M. Davarpanah, N. H. Nemati, and S. A. Tavakoli, "Fabrication of a hard tissue replacement using natural hydroxyapatite derived from bovine bones by thermal decomposition method," International Journal of Organ Transplantation Medicine, vol. 5, no. 1, pp. 23-31, 2014.

[106] A. Porzionato, M. M. Sfriso, A. Pontini et al., "Decellularized human skeletal muscle as biologic scaffold for reconstructive surgery," International Journal of Molecular Sciences, vol. 16, no. 7, pp. 14808-14831, 2015.

[107] D. Rana, H. Zreiqat, N. Benkirane-Jessel, S. Ramakrishna, and M. Ramalingam, "Development of decellularized scaffolds for stem cell-driven tissue engineering," Journal of Tissue Engineering and Regenerative Medicine, 2015.

[108] R. M. Wang and K. L. Christman, "Decellularized myocardial matrix hydrogels: in basic research and preclinical studies," Advanced Drug Delivery Reviews, vol. 96, pp. 77-82, 2016.

[109] N. Y. Anisimova, M. V. Kiselevsky, I. V. Sukhorukova, N. Shvindina, and D. Shtansky, "Fabrication method, structure, mechanical, and biological properties of decellularized extracellular matrix for replacement of wide bone tissue defects," Journal of the Mechanical Behavior of Biomedical Materials, vol. 49, pp. 255-268, 2015.

[110] G. M. Cunniffe, T. Vinardell, J. M. Murphy et al., "Porous decellularized tissue engineered hypertrophic cartilage as a scaffold for large bone defect healing," Acta Biomaterialia, vol. 23, pp. 82-90, 2015.

[111] R. Fu, Y. Wang, S. Liu et al., "Decellularization and recellularization technologies in tissue engineering," Cell Transplantation, vol. 23, no. 4, pp. 621-630, 2014.

[112] Z. J. Wang, R. Z. An, J. Y. Zhao et al., "Repair of articular cartilage defects by tissue-engineered cartilage constructed with adipose-derived stem cells and acellular cartilaginous matrix in rabbits," Genetics and Molecular Research, vol. 13, no. 2, pp. 4599-4606, 2014.

[113] X. Zhang and J. Dong, "Direct comparison of different coating matrix on the hepatic differentiation from adipose-derived stem cells," Biochemical and Biophysical Research Communications, vol. 456, no. 4, pp. 938-944, 2015.

[114] Y. Wang, C.-B. Cui, M. Yamauchi et al., "Lineage restriction of human hepatic stem cells to mature fates is made efficient by tissue-specific biomatrix scaffolds," Hepatology, vol. 53, no. 1, pp. 293-305, 2011.

[115] B. E. Uygun, A. Soto-Gutierrez, H. Yagi et al., "Organ reengineering through development of a transplantable recellularized liver graft using decellularized liver matrix," Nature Medicine, vol. 16, no. 7, pp. 814-820, 2010.

[116] M. C. Barr, J. A. Rowehl, R. R. Lunt et al., "Direct monolithic integration of organic photovoltaic circuits on unmodified paper," Advanced Materials, vol. 23, no. 31, pp. 3500-3505, 2011.

[117] H.-J. Park, S. J. Yu, K. Yang et al., "Paper-based bioactive scaffolds for stem cell-mediated bone tissue engineering," Biomaterials, vol. 35, no. 37, pp. 9811-9823, 2014.

[118] A. La Gatta, M. De Rosa, I. Marzaioli, T. Busico, and C. Schiraldi, "A complete hyaluronan hydrodynamic characterization using a size exclusion chromatography-triple detector array system during in vitro enzymatic degradation," Analytical Biochemistry, vol. 404, no. 1, pp. 21-29, 2010.

[119] C. Tonello, V. Vindigni, B. Zavan et al., "In vitro reconstruction of an endothelialized skin substitute provided with a microcapillary network using biopolymer scaffolds," The FASEB Journal, vol. 19, no. 11, pp. 1546-1548, 2005.

[120] S. Mathews, S. A. Mathew, P. K. Gupta, R. Bhonde, and S. Totey, "Glycosaminoglycans enhance osteoblast differentiation of bone marrow derived human mesenchymal stem cells," Journal of Tissue Engineering and Regenerative Medicine, vol. 8, no. 2, pp. 143-152, 2014.

[121] V. Desiderio, F. De Francesco, C. Schiraldi et al., "Human $\mathrm{Ng}^{+}$adipose stem cells loaded in vivo on a new crosslinked hyaluronic acid-lys scaffold fabricate a skeletal muscle tissue," Journal of Cellular Physiology, vol. 228, no. 8, pp. 1762-1773, 2013.

[122] J. H. Choi, J. M. Gimble, K. Lee et al., "Adipose tissue engineering for soft tissue regeneration," Tissue Engineering Part B: Reviews, vol. 16, no. 4, pp. 413-426, 2010.

[123] A. V. Vashi, E. Keramidaris, K. M. Abberton et al., "Adipose differentiation of bone marrow-derived mesenchymal stem cells using pluronic F-127 hydrogel in vitro," Biomaterials, vol. 29, no. 5, pp. 573-579, 2008.

[124] J. P. Rubin, J. M. Bennett, J. S. Doctor, B. M. Tebbets, and K. G. Marra, "Collagenous microbeads as a scaffold for tissue engineering with adipose-derived stem cells," Plastic and Reconstructive Surgery, vol. 120, no. 2, pp. 414-424, 2007.

[125] G. A. Ferraro, F. De Francesco, G. Nicoletti et al., "Human adipose CD34+ CD90+ stem cells and collagen scaffold constructs grafted in vivo fabricate loose connective and adipose tissues," Journal of Cellular Biochemistry, vol. 114, no. 5, pp. 1039-1049, 2013.

[126] L. Flynn, G. D. Prestwich, J. L. Semple, and K. A. Woodhouse, "Adipose tissue engineering in vivo with adipose-derived stem cells on naturally derived scaffolds," Journal of Biomedical Materials Research-Part A, vol. 89, no. 4, pp. 929-941, 2009.

[127] A. C. H. Ting, R. O. Craft, J. A. Palmer et al., "The adipogenic potential of various extracellular matrices under the influence of an angiogenic growth factor combination in a mouse tissue engineering chamber," Acta Biomaterialia, vol. 10, no. 5, pp. 1907-1918, 2014.

[128] J. A. Rophael, R. O. Craft, J. A. Palmer et al., "Angiogenic growth factor synergism in a murine tissue engineering model of angiogenesis and adipogenesis," The American Journal of Pathology, vol. 171, no. 6, pp. 2048-2057, 2007.

[129] S. Gomathysankar, A. S. Halim, and N. S. Yaacob, "Proliferation of keratinocytes induced by adipose-derived stem cells on a 
chitosan scaffold and its role in wound healing, a review," Archives of Plastic Surgery, vol. 41, no. 5, pp. 452-457, 2014.

[130] K. Sawada, M. Takedachi, S. Yamamoto et al., "Trophic factors from adipose tissue-derived multi-lineage progenitor cells promote cytodifferentiation of periodontal ligament cells," Biochemical and Biophysical Research Communications, vol. 464, no. 1, pp. 299-305, 2015.

[131] J. A. Plock, J. T. Schnider, W. Zhang et al., "Adipose- and bone marrow-derived mesenchymal stem cells prolong graft survival in vascularized composite allotransplantation," Transplantation, vol. 99, no. 9, pp. 1765-1773, 2015.

[132] P. H. Wu, H. Y. Chung, J. H. Wang et al., "Amniotic membrane and adipose-derived stem cell co-culture system enhances bone regeneration in a rat periodontal defect model," Journal of the Formosan Medical Association, 2015.

[133] S. Riis, V. Zachar, S. Boucher, M. Vemuri, C. P. Pennisi, and T. Fink, "Critical steps in the isolation and expansion of adiposederived stem cells for translational therapy," Expert Reviews in Molecular Medicine, vol. 17, article ell, 2015.

[134] W. Feng, S. Lv, J. Cui et al., "Histochemical examination of adipose derived stem cells combined with $\beta$-TCP for bone defects restoration under systemic administration of $1 \alpha, 25(\mathrm{OH}) 2 \mathrm{D} 3$," Materials Science and Engineering C: Materials for Biological Applications, vol. 54, pp. 133-141, 2015.

[135] P. Barba-Recreo, J. L. Del Castillo Pardo de Vera, T. GeorgievHristov et al., "Adipose-derived stem cells and platelet-rich plasma for preventive treatment of bisphosphonate-related osteonecrosis of the jaw in a murine model," Journal of CranioMaxillo-Facial Surgery, vol. 43, no. 7, pp. 1161-1168, 2015.

[136] H. Jeon, J. Kim, H. Yeo, H. Jeong, D. Son, and K. Han, “Treatment of diabetic foot ulcer using matriderm in comparison with a skin graft," Archives of Plastic Surgery, vol. 40, no. 4, pp. 403408, 2013.

[137] Y. Zayakova, A. Stanev, H. Mihailov, and N. Pashaliev, "Application of local axial flaps to scalp reconstruction," Archives of Plastic Surgery, vol. 40, no. 5, pp. 564-569, 2013.

[138] D. Garcia-Olmo, D. Herreros, I. Pascual et al., "Expanded adipose-derived stem cells for the treatment of complex perianal fistula: a phase II clinical trial," Diseases of the Colon \& Rectum, vol. 52, no. 1, pp. 79-86, 2009.

[139] X. F. Ling and X. Peng, "What is the price to pay for a free fibula flap? A systematic review of donor-site morbidity following free fibula flap surgery," Plastic and Reconstructive Surgery, vol. 129, no. 3, pp. 657-674, 2012.

[140] R. Kuang, Z. Zhang, X. Jin et al., "Nanofibrous spongy microspheres enhance odontogenic differentiation of human dental pulp stem cells," Advanced Healthcare Materials, vol. 4, no. 13, pp. 1993-2000, 2015.

[141] S. Amadori, P. Torricelli, S. Panzavolta, A. Parrilli, M. Fini, and A. Bigi, "Multi-layered scaffolds for osteochondral tissue engineering: in vitro response of co-cultured human mesenchymal stem cells," Macromolecular Bioscience, vol. 15, no. 11, pp. 15351545, 2015.

[142] H. Sano, H. Orbay, H. Terashi, H. Hyakusoku, and R. Ogawa, "Acellular adipose matrix as a natural scaffold for tissue engineering," Journal of Plastic, Reconstructive \& Aesthetic Surgery, vol. 67, no. 1, pp. 99-106, 2014.

[143] V. Hruschka, A. Saeed, P. Slezak et al., "Evaluation of a thermoresponsive polycaprolactone scaffold for in vitro threedimensional stem cell differentiation," Tissue Engineering Part A, vol. 21, no. 1-2, pp. 310-319, 2015.
[144] K. Škrlec, B. Štrukelj, and A. Berlec, "Non-immunoglobulin scaffolds: a focus on their targets," Trends in Biotechnology, vol. 33, no. 7, pp. 408-418, 2015.

[145] J. K. Kular, S. Basu, and R. I. Sharma, “The extracellular matrix: structure, composition, age-related differences, tools for analysis and applications for tissue engineering," Journal of Tissue Engineering, vol. 5, 2014. 

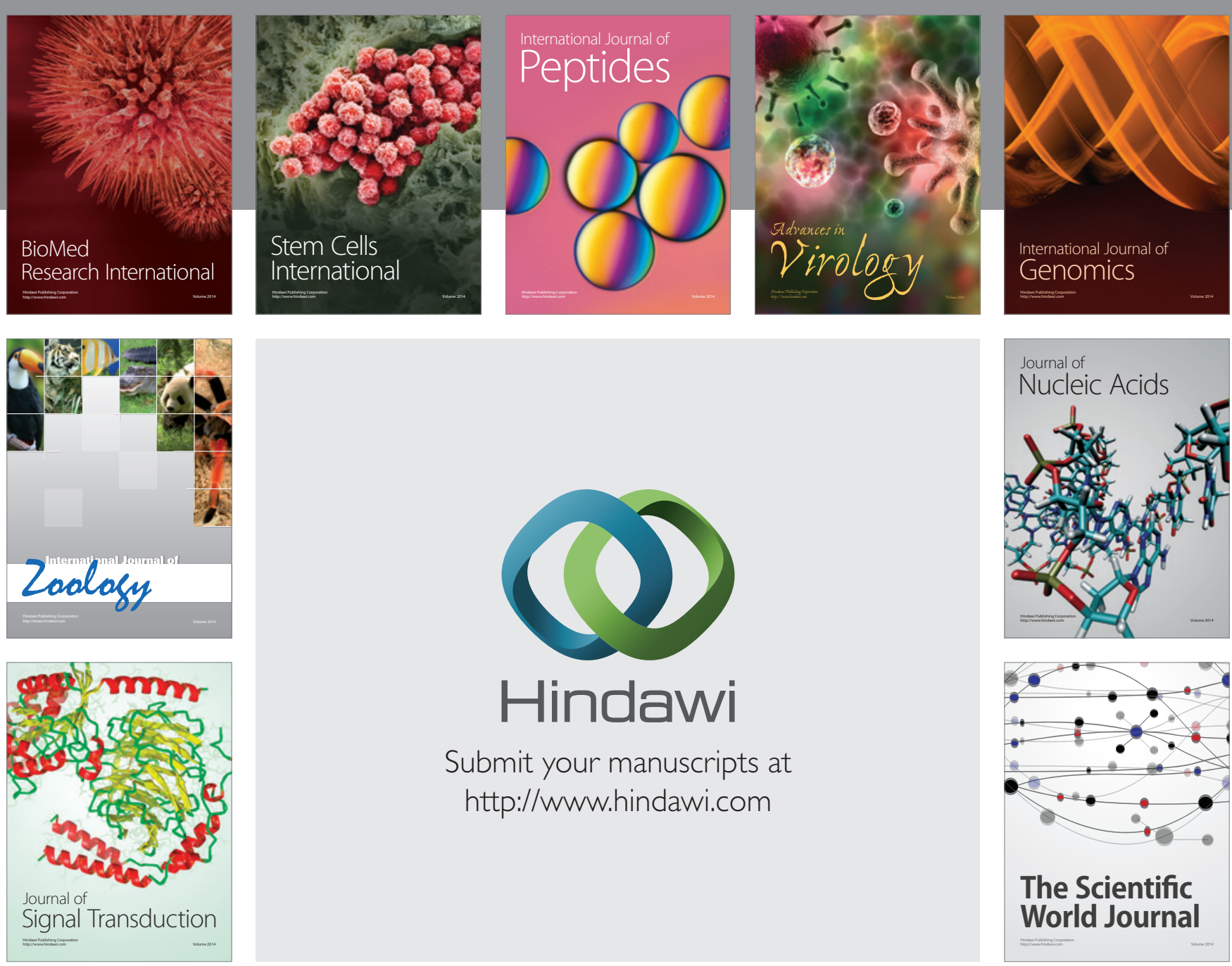

Submit your manuscripts at

http://www.hindawi.com
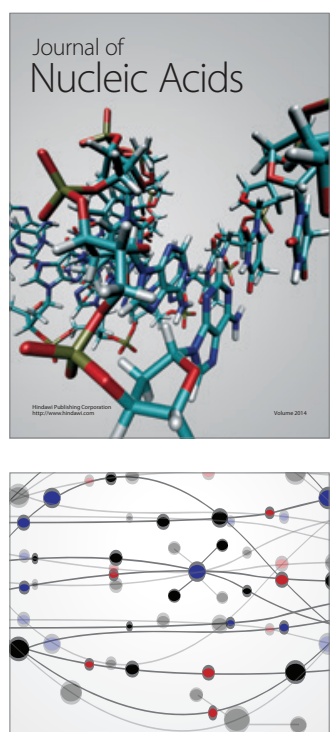

The Scientific World Journal
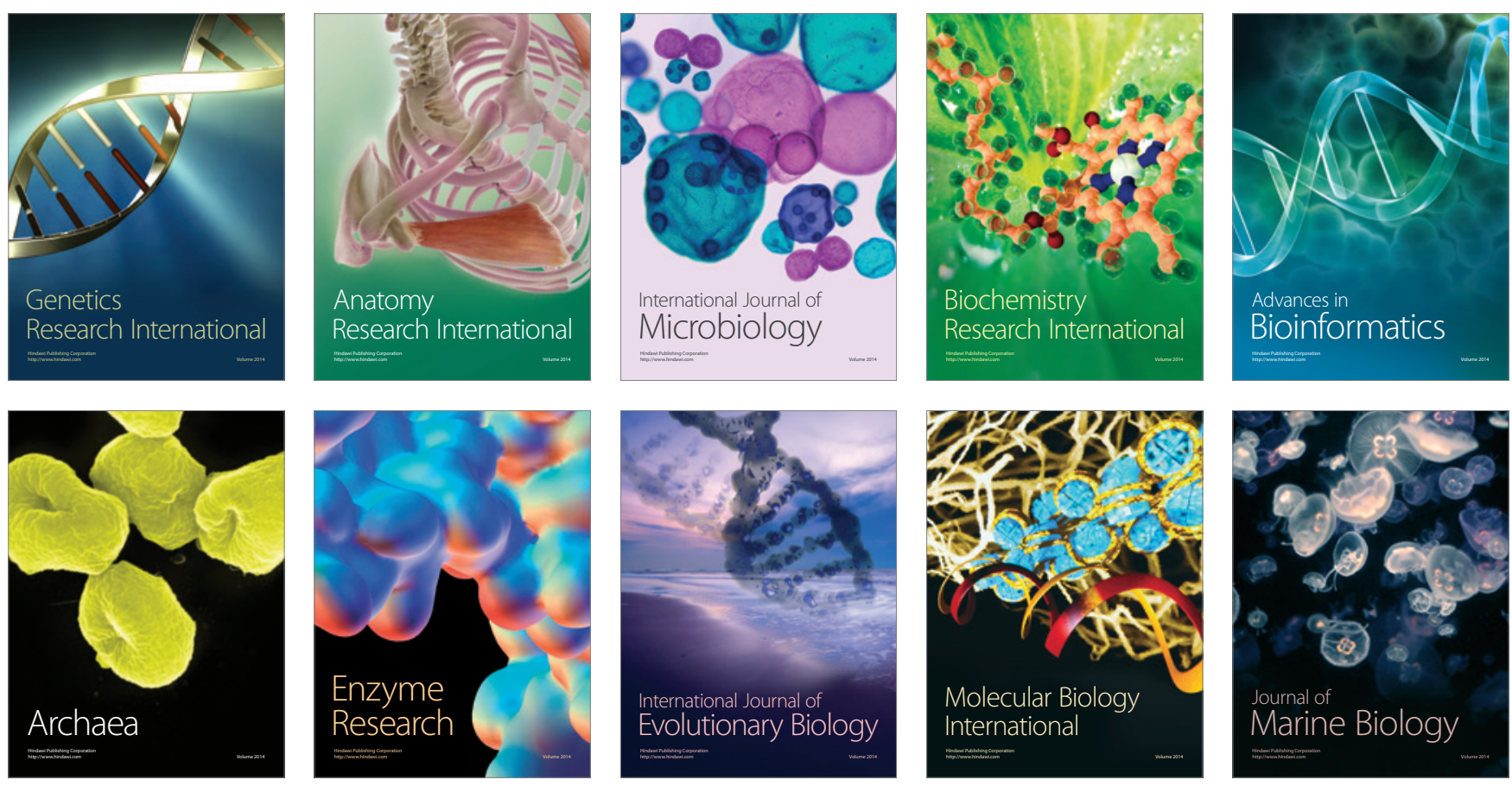